\title{
A convenient method for synthesis of tetraoxazole peptide macrocycles
}

\author{
Zhenjiang Zhang and Gu Yuan* \\ Beijing National Laboratory for Molecular Sciences, Key Laboratory of Bioorganic Chemistry \\ and Molecular Engineering of Ministry of Education, Department of Chemical Biology, College \\ of Chemistry and Molecular Engineering, Peking University, Beijing 100871, China \\ E-mail: guyuan@pku.edu.cn
}

\begin{abstract}
G-quadruplex DNA plays important regulatory roles in the maintenance of telomere length and transcriptions inhibition of such oncogenes as $c-m y c$, and thus has become an attractive target for the development of anti-cancer therapeutic agents. Poly-oxazole macrocycles are a promising new class of G-quadruplex binding ligands. Herein is described the synthesis of a tetraoxazole peptide macrocycle and an epimerization product. The synthetic unit was prepared by cyclization-oxidation of a diserine with one hydroxyl protected. Two-cycle coupling of the unit gave a linear tetraoxazole amide. The targeted molecule and the epimerization product were obtained after macrocyclization of the linear precursor and following removal of the protecting benzyl groups. With structural similarities to the most potent G-quadruplex stabilizer telomestatin, these two molecules might potentially be used to probe the biological significance of G-quadruplex' in vivo.
\end{abstract}

Keywords: G-quadruplex, poly-oxazole, anticancer drug discovery, macrocyclization, peptide

\section{Introduction}

G-quadruplex stabilization by small molecules is a promising strategy to develop anticancer therapeutic drugs. ${ }^{1}$ Many small molecules have been reported to bind to and stabilize Gquadruplex and some of them have proven to be efficacious in cancer cell lines and xenoraft tumor models. ${ }^{2}$ Telomestatin 1, (Figure 1) a natural product isolated from Streptomyces anulatus 3533-SV4, is the most potent G-quadruplex stabilizer identified ${ }^{3}$ and widely used to probe the in vivo significance of G-quadruplex. ${ }^{4}$ Telomestatin $\mathbf{1}$ has a unique macrocyclic structure consisting of seven oxazole rings and one thiazoline ring (Figure 1). Molecular modeling studies suggest that the exceptional activity of telomestatin may be attributed to the $\pi-\pi$ stacking interaction between the oxazole rings and the end G-tetrads of G-quadruplex. ${ }^{5}$ The unique structure and 
significance of biological activity have rendered telomestatin an attractive synthetic target. ${ }^{6}$ The total synthesis of telomestatin was successfully completed in $2006 .{ }^{7}$ However, the synthesis involved many steps and thus telomestatin is still not available in great quantity. Alternatively, some poly-oxazole macrocycles have emerged as a promising new class of anticancer agents that target G-quadruplex DNA. ${ }^{8}$ Here, we report the synthesis of a tetraoxazole peptide macrocycle $\mathbf{2 a}$ and an epimerization product $\mathbf{2 b}$. With structural similarities with telomestatin, these two molecules might potentially be used to probe G-quadruplex biological significance in vivo.

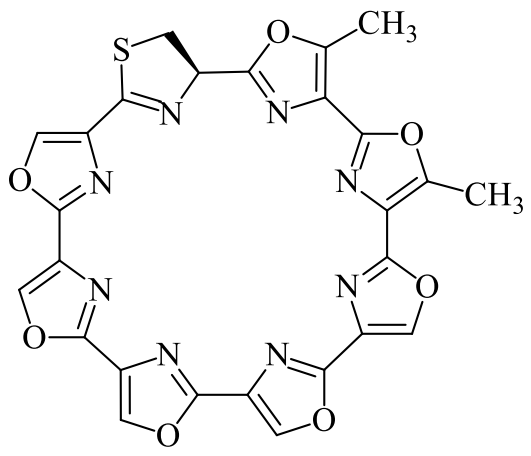

Telomestatin (1)

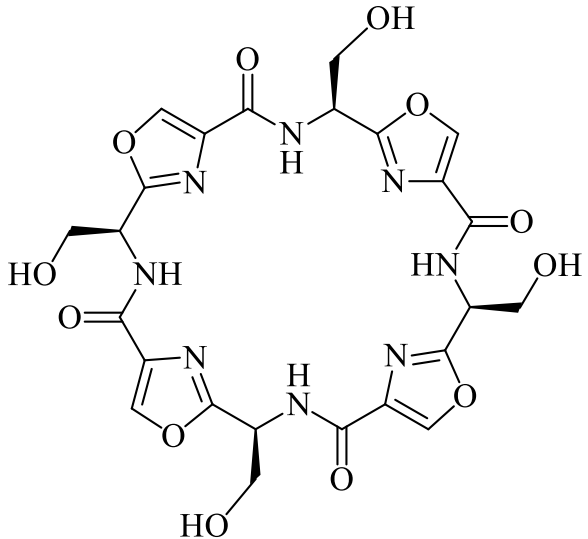

2a

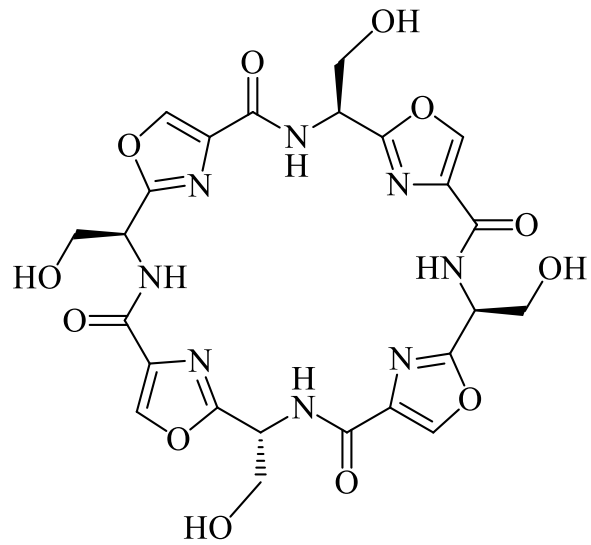

2b

Figure 1. Structure of telomestatin $\mathbf{1}$ and two tetraoxazole peptide macrocycles $\mathbf{2 a}$ and $\mathbf{2 b}$.

\section{Results and Discussion}

The biosynthesis of telomestatin has not been elucidated. A reasonable hypothesis is that it is constructed from a cyclooctapeptide containing five serine, two threonine and one cysteine. According to this, we selected Boc-L-Serine(Bzl)-OH 3 and H-L-Serine-OMe-HCl 4 as starting materials for the synthesis of 2a. (Scheme 1). 

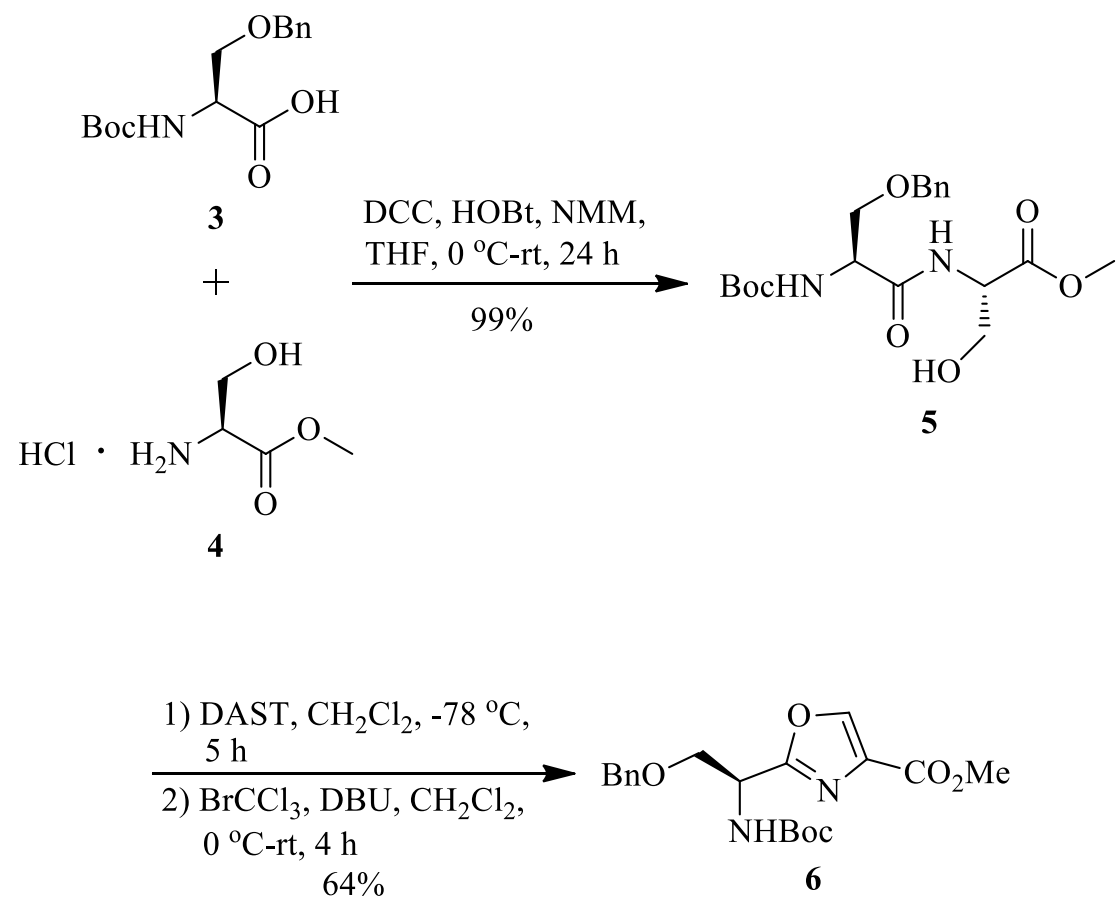

Scheme 1. Synthesis of 2,4-disubstituted oxazole unit 6.

Dipeptide 5 was readily synthesized by condensation of $\mathbf{3}$ and $\mathbf{4}$ using the $\mathrm{DCC}^{9}-\mathrm{HOBt}^{10}$ method in $99 \%$ yield. ${ }^{6 a}$ Cyclodehydration of 5 using DAST, ${ }^{11}$ followed by treatment with $\mathrm{BrCCl}_{3}-\mathrm{DBU}^{12}$ afforded 2,5-disubstituted oxazole $\mathbf{6},{ }^{6}$ to be used as the repeating unit to construct the linear tetraoxazole amide $\mathbf{8}$ (Scheme 2 ).

The resulting 2,5-disubstituted oxazole 6 was then divided into two portions, with one portion treated with $4 \mathrm{M} \mathrm{HCl}$ in ethyl acetate to remove the Boc group to give ammonium chloride $\mathbf{6} \mathbf{a}^{6 \mathrm{a}}$ and the other portion hydrolyzed with $\mathrm{LiOH}$ to give carboxylic acid $\mathbf{6 b}$. (Scheme 2) Coupling of $\mathbf{6 a}$ and $\mathbf{6 b}$ using $\mathrm{PyBroP}^{13}$ DIEA $^{14}$ gave a di-oxazole amide 7 in $69 \%$ yield. Then, the same protocol was used again to treat 7 . These two-cycle couplings afforded the linear tetraoxazole amide $\mathbf{8}$.

The precursor for macrocyclization was prepared by successive use of the hydrolysis and acidolysis treatments on $\mathbf{8}$ to remove both the methyl and Boc group (Scheme 3).

We tried both HATU ${ }^{15}$ and DPPA ${ }^{16}-\mathrm{HOBt}$ as coupling reagents for macrolactamization of $\mathbf{8}$, but only the latter in the presence of $\mathrm{DMAP}^{17}$ gave the desired product in a satisfactory yield. (Scheme 3) The reaction was performed by adding a solution of the linear precursor (10 $\mu \mathrm{mol} / \mathrm{mL})$ to a solution of DPPA-HOBt $(30 \mu \mathrm{mol} / \mathrm{mL})$ at room temperature. The crude macrocyclization product was purified by flash chromatography was then loaded on a semipreparative HPLC for further purification. The desired product 9a and an epimerization product 9b (Scheme 3) were obtained in an overall isolated yield of 20\% $(\mathbf{9 a}: \mathbf{9 b}=3: 1)$. This is easy to understand since racemization is inevitable in the long reaction time for hydrolysis, acidolysis and macrolactamization. The two products were then treated by $20 \mathrm{wt} \% \mathrm{Pd}(\mathrm{OH})_{2} / \mathrm{C}$ in a solution 
of $\mathrm{MeOH}: \mathrm{CH}_{2} \mathrm{Cl}_{2}=1: 1$ respectively to remove the protecting benzyl groups. The target molecule $\mathbf{2 a}$ and a stereomer $\mathbf{2 b}$, corresponding to $\mathbf{9 a}$ and $\mathbf{9 b}$ respectively, were obtained in a same yield $(71 \%)$.
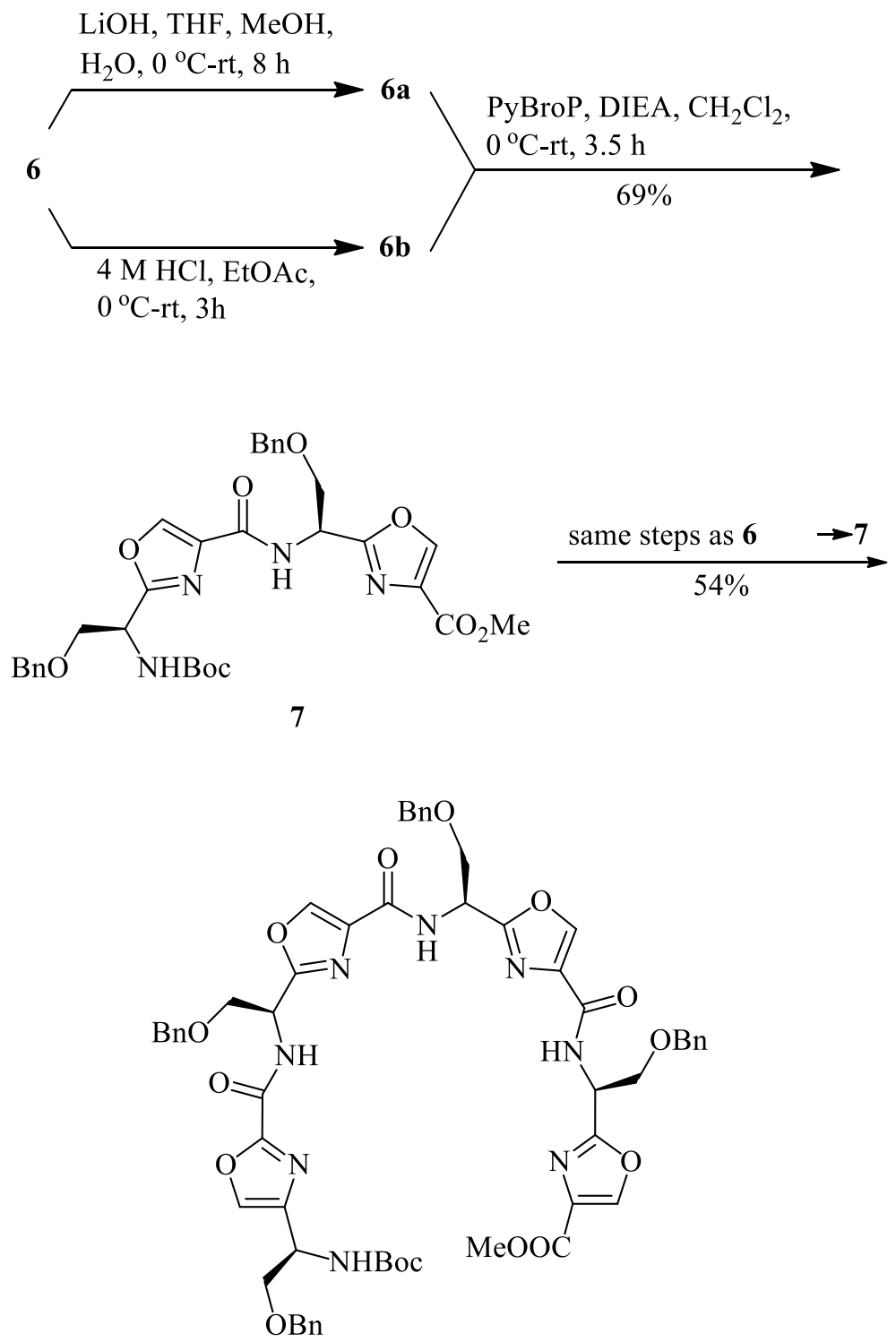

8

Scheme 2. Synthesis of linear tetraoxazole amide $\mathbf{8}$.

Poly-oxazole macrocycles have been demonstrated to selectively bind to G-quadruplex DNA and but not to duplex DNA. ${ }^{8}$ It remains to be seen whether compounds $\mathbf{2 a}$ and $\mathbf{2 b}$ could be useful in this regard. Very recently, a family of azole-modified cyclic peptides which have a core similar to that in $\mathbf{2 a}$ were reported. ${ }^{18}$ These compounds were demonstrated to be effective anion receptors. 


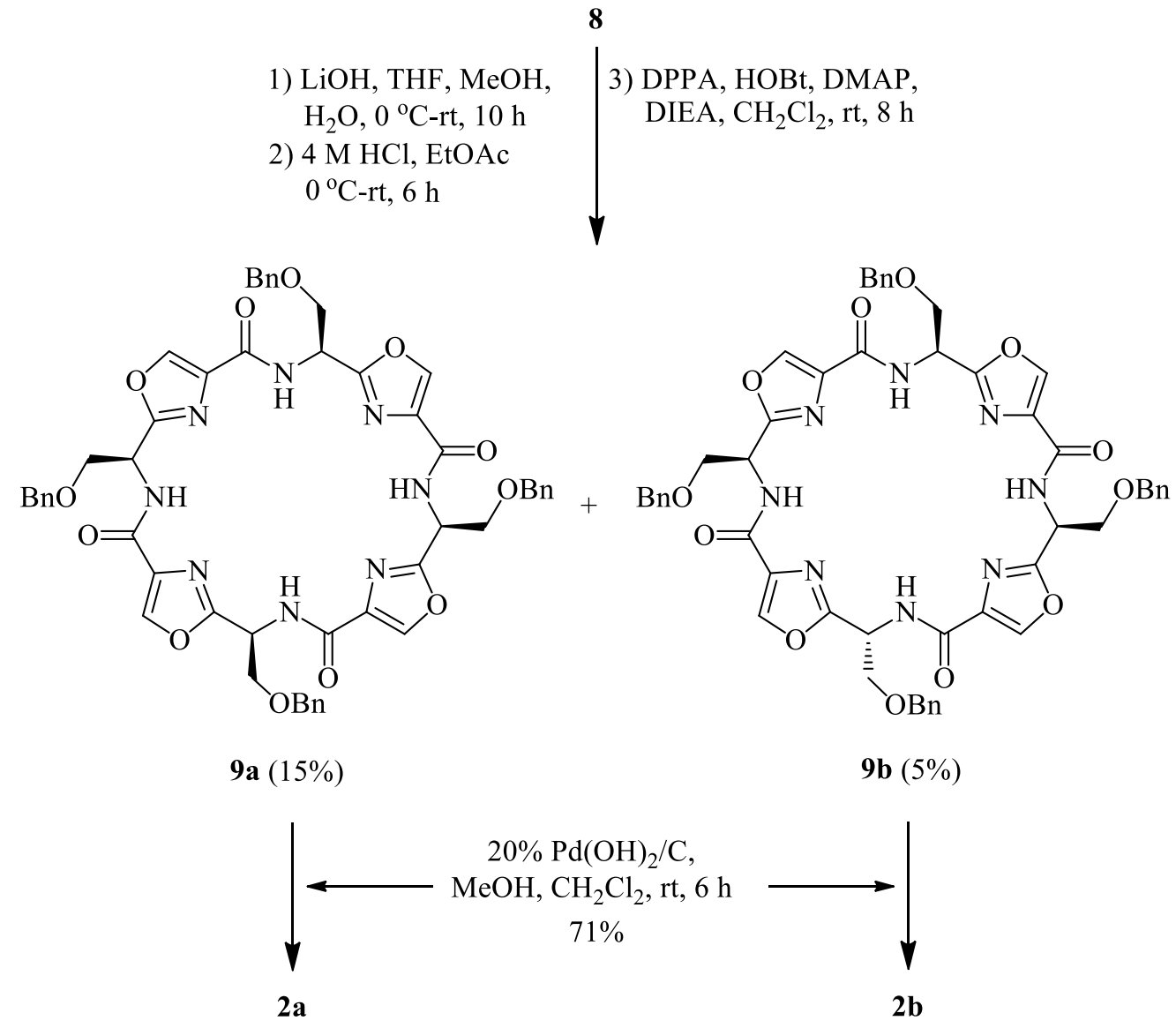

Scheme 3. Synthesis of tetraoxazole peptide macrocycles $\mathbf{2 a}$ and $\mathbf{2 b}$.

\section{Conclusions}

In conclusion, the convergent synthesis of a tetraoxazole peptide macrocycle $\mathbf{2 a}$ and an epimerization product $\mathbf{2 b}$ has been demonstrated: two-cycle couplings of the oxazole-containing synthetic unit $\mathbf{6}$ were employed, followed by macrocyclization and removal of the protecting groups. These two molecules might potentially be used to probe G-quadruplex biological significance in vivo.

\section{Experimental Section}

General. NMR spectra were recorded on Varian $300\left(300 \mathrm{MHz}\right.$ for ${ }^{1} \mathrm{H}, 75 \mathrm{MHz}$ for $\left.{ }^{13} \mathrm{C}\right)$ or a Bruker $400 \mathrm{MHz}$ NMR instrument in the indicated solvent. Chemical shifts are reported in parts per million (ppm) relative to the residual proton solvent signal for internal tetramethylsilane (7.25 ppm for ${ }^{1} \mathrm{H}$ ) for solutions in $\mathrm{CDCl}_{3}$. NMR spectral data are reported as follows: chloroform 
(7.26 ppm for $\left.{ }^{1} \mathrm{H}\right)$ or chloroform- $d\left(77.1 \mathrm{ppm}\right.$ for $\left.{ }^{13} \mathrm{C}\right)$ when the internal standard is not indicated. Multiplicities are reported by using the following abbreviations: $s$, singlet; $d$, doublet; $t$, triplet; $q$, quartet; m, multiplet; br, broad; $J$, coupling constants in Hertz. ESI-MS spectra were obtained using a Finnigan LCQ Deca XP Plus mass spectrometer. HRMS (ESI) spectra were obtained using Bruker Fourier Transform Ion Cyclotron Resonance Mass Spectrometer (APEX IV). IR spectra were recorded on AVATAR 330FT-IR THERMO NICOLET spectrophotometer. Only the strongest and/or structurally important IR absorption data is reported, given in $\mathrm{cm}^{-1}$. Optical rotations were measured with a Perkin-Elmer 341-LC polarimeter. CD spectra were recorded on a Jasco J-810 spectropolarimeter. Spectra were baseline-corrected and the signal contributions of the buffer were subtracted. Semi-preparative reversed-phase HPLC (UV $215 \mathrm{~nm}$ ) was performed on a Waters 600 system with 2996 Photodiode Array Detector. The column used was Waters Symmetry Prep C18 Column, $7 \mu \mathrm{m}, 78 \times 300 \mathrm{~mm}$.

Preparation of $N$-Boc-Ser(Bzl)-Ser-OMe (5). To a solution of $N$-Boc-L-Ser(Bzl)-OH 3 (5.91 g, $20.0 \mathrm{mmol})$ in THF $(60 \mathrm{~mL}, 3 \mathrm{~mL} / \mathrm{mmol})$ was added H-Ser-L-OMe $\bullet \mathrm{HCl} 4(3.11 \mathrm{~g}, 20.0 \mathrm{mmol})$, HOBt $(2.97 \mathrm{~g}, 22.0 \mathrm{mmol})$ and NMM $(2.4 \mathrm{~mL}, 22.0 \mathrm{mmol})$ at $\mathrm{rt}$ and the mixture was cooled to 0 ${ }^{\circ} \mathrm{C}$. To the mixture was added DCC $(4.54 \mathrm{~g}, 22.0 \mathrm{mmol})$ at the same temperature and stirred at room temperature. After being stirred at the same temperature for $24 \mathrm{~h}$, the mixture was filtered and the filtrate was concentrated in vacuo. To the resulted residue, $60 \mathrm{~mL} \mathrm{CH}_{2} \mathrm{Cl}_{2}$ was added and the undissolved solid was removed by filtration. The solution was then washed with $1 \mathrm{M} \mathrm{HCl}$, saturated aqueous $\mathrm{NaHCO}_{3}$ and brine, dried over anhydrous $\mathrm{Na}_{2} \mathrm{SO}_{4}$, and filtered. The filtrate was concentrated in vacuo. The residue was purified by column chromatography on silica gel with 50\% EtOAc in PE to afford $N$-Boc-Ser(Bzl)-Ser-OMe 5 (7.85 g, $19.8 \mathrm{mmol}, 99 \%)$ as a colorless oil. $[\alpha]_{\mathrm{D}}{ }^{20}-18.6\left(c=0.1, \mathrm{CHCl}_{3}\right) .{ }^{1} \mathrm{H} \mathrm{NMR}\left(300 \mathrm{MHz}, \mathrm{CDCl}_{3}\right) \delta 7.35-7.30(\mathrm{~m}, 5 \mathrm{H}$, phenyl), 5.43 (brd, J $5.42 \mathrm{~Hz}, 1 \mathrm{H}, \mathrm{BocNH}), 4.64$ (m, 1H, NHCH$\left(\mathrm{CH}_{2} \mathrm{Ophenyl}\right) \mathrm{CO}, 4.55$ (s, $2 \mathrm{H}$, $\underline{\mathrm{CH}}_{2}$ phenyl), $4.31\left(\mathrm{~m}, 1 \mathrm{H}, \mathrm{NHCH}\left(\mathrm{CH}_{2} \mathrm{OH}\right) \mathrm{CO}\right), 3.95-3.91\left(\mathrm{~m}, 3 \mathrm{H}, \mathrm{CH}^{\mathrm{CH}}{ }_{2} \mathrm{O}\right), 3.77(\mathrm{~s}, 3 \mathrm{H}$, $\left.\mathrm{CH}_{3} \mathrm{O}\right), 3.63\left(\mathrm{dd}, J_{1} 5.68 \mathrm{~Hz}, J_{2} 9.25 \mathrm{~Hz}, 1 \mathrm{H}, \mathrm{CHCH}_{2} \mathrm{OCH}_{2}\right), 1.45\left(\mathrm{~s}, 9 \mathrm{H},\left(\mathrm{CH}_{3}\right)_{3}\right) .{ }^{13} \mathrm{C}$ NMR $(75$ $\left.\mathrm{MHz} \mathrm{CDCl}_{3}\right) \delta 170.7,170.5,155.6,137.2,128.5,128.0,127.8,80.7,73.5,69.8,62.8,55.0,54.4$, 52.7, 28.2. FT-IR (neat) 3314, 2953, 1664, 1522, 1367, 1165, 1026, $743 \mathrm{~cm}^{-1}$. MS (ESI) calcd. for $\mathrm{C}_{19} \mathrm{H}_{28} \mathrm{~N}_{2} \mathrm{O}_{7} \mathrm{Na}[\mathrm{M}+\mathrm{Na}]^{+} 419.18$ found 419.11. HRMS (ESI) calcd. for $\mathrm{C}_{19} \mathrm{H}_{28} \mathrm{~N}_{2} \mathrm{O}_{7} \mathrm{Na}$ $[\mathrm{M}+\mathrm{Na}]^{+} 419.1789$ found 419.1795 .

Oxazole (6). To a solution of dipeptide $5(7.53 \mathrm{~g}, 19.0 \mathrm{mmol})$ in $\mathrm{CH}_{2} \mathrm{Cl}_{2}(57 \mathrm{~mL}, 3 \mathrm{~mL} / \mathrm{mmol})$ was injected a solution of DAST $(3.01 \mathrm{~mL}, 22.8 \mathrm{mmol})$ in $10 \mathrm{~mL} \mathrm{CH} \mathrm{Cl}_{2}$ at $-78{ }^{\circ} \mathrm{C}$ under $\mathrm{N}_{2}$. After being stirred at the same temperature for $5 \mathrm{~h}$, the mixture was poured into saturated aqueous $\mathrm{NaHCO}_{3}$ at $0{ }^{\circ} \mathrm{C}$. The aqueous layer was extracted twice with $\mathrm{CH}_{2} \mathrm{Cl}_{2}$. The organic layer was washed with saturated aqueous $\mathrm{NaHCO}_{3}$ and brine, dried over $\mathrm{Na}_{2} \mathrm{SO}_{4}$, and filtered. The filtrate was concentrated in vacuo. The residue was used for the next reaction without further purification.

To a solution of oxazoline in $\mathrm{CH}_{2} \mathrm{Cl}_{2}(57 \mathrm{~mL}, 3.0 \mathrm{~mL} / \mathrm{mmol})$ was added DBU (8.34 mL, 57 mmol) at $0{ }^{\circ} \mathrm{C}$. To the mixture was added dropwise $\mathrm{BrCCl}_{3}(5.62 \mathrm{~mL}, 57 \mathrm{mmol})$ at the same 
temperature. After being stirred at $\mathrm{rt}$ for $4 \mathrm{~h}$, the mixture was poured into $3 \mathrm{M} \mathrm{HCl}$ at $0{ }^{\circ} \mathrm{C}$. The aqueous layer was extracted twice with $\mathrm{CH}_{2} \mathrm{Cl}_{2}$. The organic layer was washed with $3 \mathrm{M} \mathrm{HCl}$, saturated aqueous $\mathrm{NaHCO}_{3}$, brine, dried over $\mathrm{Na}_{2} \mathrm{SO}_{4}$, and filtered. The filtrate was concentrated in vacuo. The residue was purified by column chromatography on flash silica gel with $25 \%$ EtOAc in PE to afford oxazole 6 (4.58 g, $12.2 \mathrm{mmol}, 64 \%$ in 2 steps) as a white powder. $[\alpha]_{\mathrm{D}^{20}}$ $10.6\left(c=0.1, \mathrm{CHCl}_{3}\right) .{ }^{1} \mathrm{H} \mathrm{NMR}\left(300 \mathrm{MHz}_{\mathrm{CDCl}}\right) \delta 8.20(\mathrm{~s}, 1 \mathrm{H}, \mathrm{CH}=), 7.35-7.20(\mathrm{~m}, 5 \mathrm{H}$, phenyl), 5.57 (brd, J $8.46 \mathrm{~Hz}, 1 \mathrm{H}, \operatorname{BocNH}), 5.13(\mathrm{~m}, J 4.31 \mathrm{~Hz}, 1 \mathrm{H}, \mathrm{CH}), 4.50$ (q, 2H, $\mathrm{OCH}_{2}$ phenyl), 3.92-3.90 (m, 4H, $\mathrm{CHCH}_{2} \mathrm{O}, \mathrm{CH}_{3} \mathrm{O}$ ), 3.80 (dd, J $4.41 \mathrm{~Hz}, 1 \mathrm{H}, J 9.59 \mathrm{~Hz}$, $\left.\mathrm{CHCH}_{2} \mathrm{O}\right), 1.45\left(\mathrm{~s}, 9 \mathrm{H},\left(\mathrm{CH}_{3}\right)_{3}\right) .{ }^{13} \mathrm{C} \mathrm{NMR}\left(75 \mathrm{MHz} \mathrm{CDCl}_{3}\right) \delta 163.6,161.4,155.1,144.1,137.3$, 133.3, 128.4, 127.8, 127.6, 80.4, 73.2, 70.4, 52.2, 49.3, 28.2. FT-IR (neat) 3354, 2978, 1715, $1585,1513,1454,1367,1323,1251,1166,1111,885,741 \mathrm{~cm}^{-1}$. MS (ESI) calcd. for $\mathrm{C}_{19} \mathrm{H}_{24} \mathrm{~N}_{2} \mathrm{O}_{6} \mathrm{Na}[\mathrm{M}+\mathrm{Na}]^{+} 399.15$ found 399.10. HRMS (ESI) calcd. for $\mathrm{C}_{19} \mathrm{H}_{24} \mathrm{~N}_{2} \mathrm{O}_{6} \mathrm{Na}[\mathrm{M}+\mathrm{Na}]^{+}$ 399.1527 found 399.1529 .

Di-oxazole (7) and tetra-oxazole (8). To a solution of oxazole 6 (2.26 g, $6.00 \mathrm{mmol})$ in $\mathrm{MeOH}$ (12.0 mL, $2.0 \mathrm{~mL} / \mathrm{mmol})$, THF (12.0 mL, $2.0 \mathrm{~mL} / \mathrm{mmol})$ and $\mathrm{H}_{2} \mathrm{O}(1.2 \mathrm{~mL}, 0.2 \mathrm{~mL} / \mathrm{mmol})$ was added $\mathrm{LiOH} \cdot \mathrm{H}_{2} \mathrm{O}(252 \mathrm{mg}, 6.00 \mathrm{mmol})$ at $0{ }^{\circ} \mathrm{C}$. The mixture was allowed to warm to $\mathrm{rt}$ over $2 \mathrm{~h}$. After being stirred at the same temperature for another $6 \mathrm{~h}$, the mixture was acidified with $3 \mathrm{M}$ $\mathrm{HCl}$ at $0{ }^{\circ} \mathrm{C}$. The aqueous layer was extracted twice with $\mathrm{CH}_{2} \mathrm{Cl}_{2}$. The organic layer was washed with brine, dried over $\mathrm{Na}_{2} \mathrm{SO}_{4}$, and filtered. The filtrate was concentrated in vacuo. The crude acid 6a was used for next reaction without further purification.

To another solution of oxazole $6(2.26 \mathrm{~g}, 6.00 \mathrm{mmol})$ in EtOAc $(10 \mathrm{~mL})$ was added $4 \mathrm{M} \mathrm{HCl}$ in EtOAc $(40 \mathrm{~mL})$ at $0{ }^{\circ} \mathrm{C}$. After being stirred at the same temperature for $3 \mathrm{~h}$, the solvent was removed under reduced pressure. The crude ammonium hydrochloride $\mathbf{6 b}$ was used for the next reaction without further purification.

To a solution of the resulted crude $\mathbf{6 a}$ in $\mathrm{CH}_{2} \mathrm{Cl}_{2}(60 \mathrm{~mL}, 10 \mathrm{~mL} / \mathrm{mmol})$ was added the $\mathbf{6 b}$, DIEA $(4.96 \mathrm{~mL}, 30.0 \mathrm{mmol})$ and the mixture was cooled to $0{ }^{\circ} \mathrm{C}$. To the mixture was added PyBroP $(4.20 \mathrm{~g}, 9.00 \mathrm{mmol})$ at the same temperature. The mixture was allowed to warm up to $\mathrm{rt}$ over $2 \mathrm{~h}$. After being stirred at the same temperature for another $1.5 \mathrm{~h}$, the mixture was poured into $1 \mathrm{M}$ $\mathrm{HCl}$ at $0{ }^{\circ} \mathrm{C}$. The aqueous layer was extracted twice with $\mathrm{CH}_{2} \mathrm{Cl}_{2}$. The organic layer was washed with $3 \mathrm{M} \mathrm{HCl}$, saturated aqueous $\mathrm{NaHCO}_{3}$ and brine, dried over $\mathrm{Na}_{2} \mathrm{SO}_{4}$, and filtered. The filtrate was concentrated in vacuo. The residue was purified by column chromatography on flash silica gel with 50\% PE in EtOAc to afford di-oxazole 7 (2.57 g, $4.14 \mathrm{mmol}, 69 \%)$. $[\alpha]_{\mathrm{D}}{ }^{20}-12.7(c$ $\left.=0.1, \mathrm{CHCl}_{3}\right) .{ }^{1} \mathrm{H} \mathrm{NMR}\left(300 \mathrm{MHz}_{\mathrm{CDCl}}\right) \delta 8.20(\mathrm{~s}, 1 \mathrm{H}, \mathrm{CH}=), 8.19(\mathrm{~s}, 1 \mathrm{H}, \mathrm{CH}=), 7.76(\mathrm{brd}, J$ $8.60 \mathrm{~Hz}, 1 \mathrm{H}, \mathrm{NH}), 7.35-7.21$ (m, 10H, phenyl), 5.60 (dt, J 4.32 Hz, J 8.69 Hz, 1H, CH), 5.53 (brd, J 7.45 Hz, 1H, BocNH), $5.10(\mathrm{~m}, 1 \mathrm{H}, \mathrm{b}), 4.60-4.48$ (m, 4H, $\underline{\mathrm{CH}}_{2}$ phenyl), 4.03 (dd, J 4.48 $\mathrm{Hz}, J 9.69 \mathrm{~Hz}, 1 \mathrm{H}, \mathrm{CHCH}_{2} \mathrm{O}$ ), 3.93-3.86 (m, 5H, $\underline{\mathrm{CH}_{2}}$ phenyl, $\mathrm{CHCH}_{2} \mathrm{O}$ ), 3.82 (dd, $J 4.08 \mathrm{~Hz}, J$ $\left.9.48 \mathrm{~Hz}, 1 \mathrm{H}, \mathrm{CHCH}_{2} \mathrm{O}\right), 1.46\left(\mathrm{~s}, 9 \mathrm{H},\left(\mathrm{CH}_{3}\right)_{3}\right) .{ }^{13} \mathrm{C} \mathrm{NMR}\left(75 \mathrm{MHz} \mathrm{CDCl}_{3}\right) \delta 162.6,162.5,161.3$, 160.3, 155.2, 144.2, 142.0, 137.1, 135.4, 133.4, 128.4, 127.9, 127.7, 127.6, 80.5, 73.3, 73.2, 70.1, 69.7, 52.2, 49.4, 47.3, 28.2. FT-IR (neat) 3308, 2978, 2873, 1715, 1597, 1508, 1454, 1366, 1323, 
1250, 1166, 1108, 863, $738 \mathrm{~cm}^{-1}$. MS (ESI) calcd. for $\mathrm{C}_{32} \mathrm{H}_{36} \mathrm{~N}_{4} \mathrm{O}_{9} \mathrm{Na}[\mathrm{M}+\mathrm{Na}]^{+} 643.24$ found 643.15. HRMS (ESI) calcd. for $\mathrm{C}_{32} \mathrm{H}_{36} \mathrm{~N}_{4} \mathrm{O}_{9} \mathrm{Na}[\mathrm{M}+\mathrm{Na}]^{+} 643.2374$ found 643.2371.

The same saponification, acidolysis, coupling treatments (same ratios of reactants, reagents, concentrations of reaction solutions and reaction time) and same work-up protocols as above were used to prepare tetra-oxazole 8 from di-oxazole 7 with the exception that 1.5 equiv., instead of 1.0 equiv. $\mathrm{LiOH} \cdot \mathrm{H}_{2} \mathrm{O}$ was used for saponification and an eluant of $25 \%$, instead of $50 \%$, $\mathrm{PE}$ in EtOAc was used for separation and purification of tetra-oxazole 8 (1.20 g, $1.08 \mathrm{mmol}, 54 \%)$ by column chromatography. $[\alpha]_{\mathrm{D}}{ }^{20}-10.7\left(c=0.1, \mathrm{CHCl}_{3}\right) .{ }^{1} \mathrm{H} \mathrm{NMR}\left(300 \mathrm{MHz} \mathrm{CDCl}_{3}\right) \delta 8.19(\mathrm{~s}, 1 \mathrm{H}$, $\mathrm{OCH}=), 8.18(\mathrm{~s}, 1 \mathrm{H}, \mathrm{OCH}=), 8.17(\mathrm{~s}, 1 \mathrm{H}, \mathrm{OCH}=), 8.16(\mathrm{~s}, 1 \mathrm{H}, \mathrm{OCH}=), 7.67$ (brd, 4H, NH), 7.33-7.18 (m, 20H, phenyl), 5.57 (m, 3H, CH), 5.46 (brd, J 8.38 Hz, 1H, BocNH), 5.07 (m, 1H, $\mathrm{CH})$, 4.61-4.29 (m, 8H, $\underline{\mathrm{CH}}_{2}$ phenyl), 4.03-3.77 (m, 11H, $\left.\mathrm{CH}_{3}, \mathrm{CHCH}_{2} \mathrm{O}\right), 1.44$ (s, 9H, $\left.\left(\mathrm{CH}_{3}\right)_{3}\right)$. ${ }^{13} \mathrm{C}$ NMR $\left(75 \mathrm{MHz} \mathrm{CDCl}_{3}\right)$ 8162.6, 162.4, 161.54, 161.51, 161.3, 160.1, 160.0, 155.1, 144.1, 141.94, 141.88, 141.79, 127.77, 127.6, 127.5, 80.3, 73.14, 73.07, 70.0, 69.7, 69.51, 69.47, 65.5, 52.0, 49.3, 47.26, 47.21, 28.2. FT-IR (neat) 3269, 2978, 1718, 1669, 1600, 1521, 1454, 1366, 1323, 1207, 1167, 1108, 869, $740 \mathrm{~cm}^{-1}$. MS (ESI) calcd. for $\mathrm{C}_{58} \mathrm{H}_{60} \mathrm{~N}_{8} \mathrm{O}_{15} \mathrm{Na}[\mathrm{M}+\mathrm{Na}]^{+} 1131.41$ found 1131.36. HRMS (ESI) calcd. for $\mathrm{C}_{58} \mathrm{H}_{60} \mathrm{~N}_{8} \mathrm{O}_{15} \mathrm{Na}[\mathrm{M}+\mathrm{Na}]^{+} 1131.4070$ found 1131.4091 .

Macrolactams (9a) and (9b). To a solution of tetra-oxazole 8 (100 mg, $0.09 \mathrm{mmol})$ in $\mathrm{MeOH}$ $(6.3 \mathrm{~mL}, 70 \mathrm{~mL} / \mathrm{mmol})$, THF $(6.3 \mathrm{~mL}, 70 \mathrm{~mL} / \mathrm{mmol})$ and $\mathrm{H}_{2} \mathrm{O}(0.27 \mathrm{~mL}, 3 \mathrm{~mL} / \mathrm{mmol})$ was added $\mathrm{LiOH} \cdot \mathrm{H}_{2} \mathrm{O}(37.8 \mathrm{mg}, 0.9 \mathrm{mmol})$ at $0{ }^{\circ} \mathrm{C}$. The mixture was allowed to warm up to $\mathrm{rt}$ over $2 \mathrm{~h}$. After being stirred at the same temperature for another $8 \mathrm{~h}$, the mixture was acidified with $3 \mathrm{M}$ $\mathrm{HCl}$ at $0{ }^{\circ} \mathrm{C}$. The aqueous layer was extracted twice with $\mathrm{CH}_{2} \mathrm{Cl}_{2}$. The organic layer was washed with brine, dried over $\mathrm{Na}_{2} \mathrm{SO}_{4}$, and filtered. The filtrate was concentrated in vacuo.

The above crude acid was taken up in $5 \mathrm{~mL}$ EtOAc. To the mixture was added $4 \mathrm{M} \mathrm{HCl}$ in EtOAc $(20 \mathrm{~mL})$ at $0{ }^{\circ} \mathrm{C}$. After being stirred at the same temperature for $6 \mathrm{~h}$, the solvent was removed under reduced pressure. The residue was used for the next reaction without further purification.

To a solution of DPPA (2.7 mmol), HOBt $(2.7 \mathrm{mmol})$, DIEA $(3.6 \mathrm{mmol})$ and DMAP (0.09 mmol) in $\mathrm{CH}_{2} \mathrm{Cl}_{2}(35 \mathrm{~mL})$ was added dropwise a solution of the above residue in $10 \mathrm{~mL} \mathrm{CH}_{2} \mathrm{Cl}_{2}$ over $4 \mathrm{~h}$ at $\mathrm{rt}$. After being stirred at the same temperature for another $4 \mathrm{~h}$, the mixture was poured into $1 \mathrm{M} \mathrm{HCl}$ at $0{ }^{\circ} \mathrm{C}$. The aqueous layer was extracted twice with $\mathrm{CH}_{2} \mathrm{Cl}_{2}$. The organic layer was washed with $3 \mathrm{M} \mathrm{HCl}$, saturated aqueous $\mathrm{NaHCO}_{3}$ and brine, dried over $\mathrm{Na}_{2} \mathrm{SO}_{4}$, and filtered. The filtrate was concentrated in vacuo. The residue was purified by column chromatography on flash silica gel with 50\% EtOAc in PE, and by semi-preparative HPLC eluting with $\mathrm{H}_{2} \mathrm{O}: \mathrm{MeCN}: \mathrm{CF}_{3} \mathrm{COOH}=52: 48: 0.5$ to afford macrolactam 9a $\left(\mathrm{t}_{\mathrm{R}}=62.8 \mathrm{~min}\right.$, $13.2 \mathrm{mg}, 13.5 \mu \mathrm{mmol}, 15 \%)$ and $9 \mathrm{~b}\left(\mathrm{t}_{\mathrm{R}}=52.3 \mathrm{~min} 4.4 \mathrm{mg}, 4.5 \mu \mathrm{mmol}, 5 \%\right)$, each as a white powder.

9a. $[\alpha]_{\mathrm{D}}{ }^{20}-1.8\left(c=0.1, \mathrm{CHCl}_{3}\right) .{ }^{1} \mathrm{H} \mathrm{NMR}\left(300 \mathrm{MHz} \mathrm{CDCl}_{3}\right) \delta 8.26(\mathrm{~s}, 4 \mathrm{H}, \mathrm{CH}=), 8.05$ (brd, $J$ $9.56 \mathrm{~Hz}, 4 \mathrm{H}, \mathrm{NH}), 7.28-7.14(\mathrm{~m}, 20 \mathrm{H}$, phenyl, $5.73(\mathrm{~m}, 4 \mathrm{H}, \mathrm{CH}), 4.59-4.44(\mathrm{~m}, 8 \mathrm{H}$, $\mathrm{OCH}_{2}$ phenyl), 3.94 (dd, J $3.89 \mathrm{~Hz}, J 9.06 \mathrm{~Hz}, 4 \mathrm{H}, \mathrm{CHCH}_{2} \mathrm{O}$ ), 3.82 (dd, J $3.70 \mathrm{~Hz}, J 9.48 \mathrm{~Hz}$, $\left.4 \mathrm{H}, \mathrm{CHCH}_{2} \mathrm{O}\right) .{ }^{13} \mathrm{C} \mathrm{NMR}\left(75 \mathrm{MHz} \mathrm{CDCl}_{3}\right) \delta 161.9,159.9,142.5,137.0,135.7,128.4,127.9$, 
127.7, 73.2, 69.9, 47.4. FT-IR (neat) 3400, 2920, 1676, 1599, 1512, 1454, 1364, 1204, 1103, 873, $735 \mathrm{~cm}^{-1}$. MS (ESI) calcd. for $\mathrm{C}_{52} \mathrm{H}_{48} \mathrm{~N}_{8} \mathrm{O}_{12} \mathrm{Na}[\mathrm{M}+\mathrm{Na}]^{+} 999.33$ found 999.35. HRMS (ESI) calcd. for $\mathrm{C}_{52} \mathrm{H}_{48} \mathrm{~N}_{8} \mathrm{O}_{12} \mathrm{Na}[\mathrm{M}+\mathrm{Na}]^{+} 999.3284$ found 999.3294 .

9b. $[\alpha]_{\mathrm{D}}{ }^{20}-15.3\left(c=0.1, \mathrm{CHCl}_{3}\right) .{ }^{1} \mathrm{H}$ NMR $\left(300 \mathrm{MHz} \mathrm{CDCl}_{3}\right) \delta 8.27(\mathrm{~s}, 1 \mathrm{H}, \mathrm{CH}=), 8.26$ (s,1H,CH=), $8.23(\mathrm{~s}, 1 \mathrm{H}, \mathrm{CH}=), 8.22(\mathrm{~s}, 1 \mathrm{H}, \mathrm{CH}=), 7.95(\mathrm{~d}, J 9.26 \mathrm{~Hz}, 1 \mathrm{H}, \mathrm{NH}), 7.76(\mathrm{~d}, J 9.21$ $\mathrm{Hz}, 1 \mathrm{H}, \mathrm{NH}), 7.72(\mathrm{~d}, J 8.16 \mathrm{~Hz}, 1 \mathrm{H}, \mathrm{NH}), 7.57(\mathrm{~d}, J 9.61 \mathrm{~Hz}, 1 \mathrm{H}, \mathrm{NH}), 7.30-7.07(\mathrm{~m}, 20 \mathrm{H}$, phenyl), 5.81-5.58 (m, 4H, CH), 4.63-4.38 (m, 8H, $\underline{\mathrm{CH}}_{2}$ phenyl), 4.09-3.75 (m, 8H, $\mathrm{CHCH}_{2} \mathrm{O}$ ). 13C NMR (75 MHz $\left.\mathrm{CDCl}_{3}\right) \delta 162.6,162.1,162.0,161.7,160.1,159.9,159.8,142.6,142.5$, $142.3,141.7,137.2,136.85,136.80,135.84,135.81,135.77,135.3,135.3,128.6,128.48,128.45$, 128.43, 128.2, 128.1, 127.91, 127.86, 127.76, 127.72, 127.64, 127.59, 73.4, 73.3, 73.2, 73.1, 70.3, 70.13, 70.08, 69.6, 47.6, 47.3, 47.2, 45.7. FT-IR (neat) 3407, 3045, 1676, 1598, 1507, 1454, 1363, 1202, 1104, 869, $736 \mathrm{~cm}^{-1}$. MS (ESI) calcd. for $\mathrm{C}_{52} \mathrm{H}_{48} \mathrm{~N}_{8} \mathrm{O}_{12} \mathrm{Na}[\mathrm{M}+\mathrm{Na}]^{+} 999.33$ found 999.36. HRMS (ESI) HRMS (ESI) calcd. for $\mathrm{C}_{52} \mathrm{H}_{48} \mathrm{~N}_{8} \mathrm{O}_{12} \mathrm{Na}[\mathrm{M}+\mathrm{Na}]^{+} 999.3284$ found 999.3298.

Macrocycles (2a) and (2b). To $\mathrm{Pd}(\mathrm{OH})_{2} / \mathrm{C}(50 \mathrm{mg}, 20 \mathrm{wt} \%)$ was added a solution of $9 \mathbf{a}(5.0 \mathrm{mg}$, $5.12 \mu \mathrm{mol})$ in $\mathrm{CH}_{2} \mathrm{Cl}_{2}(2.5 \mathrm{~mL}, 125 \mathrm{~mL} / \mathrm{mmol})$ and $\mathrm{MeOH}(2.5 \mathrm{~mL}, 125 \mathrm{~mL} / \mathrm{mmol})$ at rt. The reaction vessel was purged with $\mathrm{H}_{2}$ three times. After being stirred for $3 \mathrm{~h}$, the mixture was filtered through a pad of Celite and the filtrate was concentrated in vacuo. The residue was purified by semi-preparative HPLC eluted with $\mathrm{H}_{2} \mathrm{O}: \mathrm{CH}_{3} \mathrm{CN}: \mathrm{CF}_{3} \mathrm{COOH}=88: 12: 0.1$ to afford $2 \mathrm{a}\left(\mathrm{t}_{\mathrm{R}}=15.5 \mathrm{~min}, 2.24 \mathrm{mg}, 3.64 \mu \mathrm{mmol}, 71 \%\right)$ and as a white powder. $[\alpha]_{\mathrm{D}}{ }^{20}-6.6(c=$ $\left.0.1, \mathrm{H}_{2} \mathrm{O}\right) . \mathrm{CD}\left(\mathrm{H}_{2} \mathrm{O}, c=1.0 \times 10^{-5} \mathrm{M}\right) \Delta \varepsilon 82,000 .{ }^{1} \mathrm{H}$ NMR $\left(400 \mathrm{MHz} \mathrm{D}_{2} \mathrm{O}\right) \delta 8.44(\mathrm{~s}, 4 \mathrm{H}$, $\mathrm{CH}=), 5.52(\mathrm{t}, J 5.57 \mathrm{~Hz}, 4 \mathrm{H}, \underline{\mathrm{CH}}), 4.16\left(\mathrm{dq}, J 5.49 \mathrm{~Hz}, J 6.13 \mathrm{~Hz}, J 11.33 \mathrm{~Hz}, 8 \mathrm{H}, \mathrm{CH}_{2}\right), 3.37$ (s, c, partially exchanged with $\left.\mathrm{D}_{2} \mathrm{O}\right) .{ }^{13} \mathrm{C}$ NMR $\left(100 \mathrm{MHz} \mathrm{D}_{2} \mathrm{O}\right) \delta 162.2,161.6,143.7,134.4$, 61.1, 48.5. FT-IR (neat) 3390, 2973, 2360, 1676, 1600, 1520, 1400, 1200, 1140, 833, $740 \mathrm{~cm}^{-1}$. MS (ESI) calcd. for $\mathrm{C}_{24} \mathrm{H}_{25} \mathrm{~N}_{8} \mathrm{O}_{12}[\mathrm{M}+\mathrm{H}]^{+} 617.16$ found 617.14; calcd. for $\mathrm{C}_{24} \mathrm{H}_{24} \mathrm{~N}_{8} \mathrm{O}_{12} \mathrm{Na}$ $[\mathrm{M}+\mathrm{Na}]+639.14$ found 639.20. HRMS (ESI) calcd. for $\mathrm{C}_{24} \mathrm{H}_{24} \mathrm{~N}_{8} \mathrm{O}_{12} \mathrm{Na}[\mathrm{M}+\mathrm{Na}]^{+} 639.1406$ found 639.1400; calcd. for $\mathrm{C}_{24} \mathrm{H}_{24} \mathrm{~N}_{8} \mathrm{O}_{12} \mathrm{~K}[\mathrm{M}+\mathrm{K}]^{+} 655.1145$ found 655.1138 .

2b. $\left(\mathrm{t}_{\mathrm{R}}=8.7 \mathrm{~min}, 1.79 \mathrm{mg}, 2.90 \mu \mathrm{mmol}, 71 \%\right)$ as a white powder was synthesized by using the same protocol as above. $[\alpha]_{\mathrm{D}}{ }^{20}-15.4\left(c=0.1, \mathrm{H}_{2} \mathrm{O}\right) .{ }^{1} \mathrm{H}$ NMR $\left(400 \mathrm{MHz} \mathrm{H}_{2} \mathrm{O}\right) \delta 8.51(\mathrm{~s}, 1 \mathrm{H}$, $\mathrm{CH}=), 8.49(\mathrm{~s}, 1 \mathrm{H}, \mathrm{CH}=), 8.48(\mathrm{~s}, 1 \mathrm{H}, \mathrm{CH}=), 8.45(\mathrm{~s}, 1 \mathrm{H}, \mathrm{CH}=), 5.57(\mathrm{t}, J 5.22 \mathrm{~Hz}, 1 \mathrm{H}, \mathrm{CH})$, 5.52-5.47 (m, 3H, CH), 4.19-4.08 (m, 8H, $\left.\mathrm{CH}_{2}\right), 3.37$ (s, c, partilly exchanged with $\left.\mathrm{D}_{2} \mathrm{O}\right) .{ }^{13} \mathrm{C}$ NMR $\left(100 \mathrm{MHz} \mathrm{D}_{2} \mathrm{O}\right) \delta 162.4,162.3,162.21,162.18,162.0,161.9,161.83,161.77,144.6$, 143.62, 143.58, 143.1, 134.64, 134.60, 134.5, 134.3, 62.2, 62.0, 61.3, 61.2, 49.4, 49.21, 49.18, 48.6. FT-IR (neat) 3361, 2935, 2395, 1664, 1598, 1519, 1443, 1204, 1120, 830, $726 \mathrm{~cm}^{-1}$. MS (ESI) calcd. for ${ }_{24} \mathrm{H}_{25} \mathrm{~N}_{8} \mathrm{O}_{12}[\mathrm{M}+\mathrm{H}]^{+} 617.16$ found 617.09 ; calcd. for $\mathrm{C}_{24} \mathrm{H}_{24} \mathrm{~N}_{8} \mathrm{O}_{12} \mathrm{Na}[\mathrm{M}+\mathrm{Na}]^{+}$ 639.14 found 639.24. HRMS (ESI) $\mathrm{C}_{24} \mathrm{H}_{25} \mathrm{~N}_{8} \mathrm{O}_{12}[\mathrm{M}+\mathrm{H}]^{+} 617.1586$ found 617.1580; calcd. for calcd. for $\mathrm{C}_{24} \mathrm{H}_{24} \mathrm{~N}_{8} \mathrm{O}_{12} \mathrm{Na}[\mathrm{M}+\mathrm{Na}]^{+} 639.1406$ found 639.1394; calcd. for $\mathrm{C}_{24} \mathrm{H}_{24} \mathrm{~N}_{8} \mathrm{O}_{12} \mathrm{~K}[\mathrm{M}+\mathrm{K}]^{+}$ 655.1145 found 655.1136 . 


\section{Acknowledgements}

This project was supported by the National Natural Science Foundation of China (No.20872008, 90913004). We thank Dr. Hongfang Sun for providing the facility of semi-preparative HPLC for product purification.

\section{References and Notes}

1. Neidle, S. FEBS Journal 2010, 277, 1118.

2. (a) Neidle, S.; Parkinson, G. Nat. Rev. Drug Discov. 2002, 1, 383. (b) Monchaud, D.; Teulade-Fichou, M. P. Org. Biomol. Chem. 2008, 6, 627. (c) Drygin, D.; Siddiqui-Jain, A.; O'Brien, S.; Schwaebe, M.; Lin, A.; Bliesath, J.; Ho, C. B.; Proffitt, C.; Trent, K.; Whitten, J. P.; Lim, J. K.; Von Hoff, D.; Anderes, K.; Rice, W. G. Cancer Res. 2009, 69, 7653.

3. (a) Shin-ya, K.; Wierzba, K.; Matsuo, K.; Ohtani, T.; Yamada, Y.; Furihata, K.; Hayakawa, Y.; Seto, H. J. Am. Chem. Soc. 2001, 123, 1262. (b) Kim, M. Y.; Vankayalapati, H.; ShinYa, K.; Wierzba, K.; Hurley, L. H. J. Am. Chem. Soc. 2002, 124, 2098.

4. (a) Kim, M. Y.; Gleason-Guzman, M.; Izbicka, E.; Nishioka, D.; Hurley, L. H. Cancer Res. 2003, 63, 3247. (b) Gomez, D.; Wenner, T.; Brassart, B.; Douarre, C.; O'Donohue, M. F.; El Khoury, V.; Shin-Ya, K.; Morjani, H.; Trentesaux, C.; Riou, J. F. J. Biol. Chem. 2006, 281, 38721. (c) Sumi, M.; Tauchi, T.; Sashida, G.; Nakajima, A.; Gotoh, A.; Shin-Ya, K.; Ohyashiki, J. H.; Ohyashiki, K. Int. J. Oncol. 2004, 24, 1481.

5. (a) 3b. (b) Agrawal, S.;Ojha, R. P.; Maiti, S. J. Phys. Chem. B.2008, 112, 6828.

6. (a) Deeley, J.; Bertram, A.; Pattenden, G. Org. Biomol. Chem. 2008, 6, 1994. (b) Atkins, J. M.;Vedejs, E. Org. Lett. 2005, 7, 3351. (c) Chattopadhyay, S. K.; Biswas, S. Tetrahedron Lett. 2006, 47, 7897.

7. Doi, T.;Yoshida, M.;Shin-ya, K.;Takahashi, T. Org. Lett. 2006, 8, 4165.

8. Minhas, G. S.; Pilch, D. S.; Kerrigan, J. E.; LaVoie, E. J.; Rice, J. E. Bioorg. Med. Chem. Lett. 2006, 16, 3891. (b) Rzuczek, S. G.; Pilch, D. S.; LaVoie, E. J.; Rice, J. E. Bioorg. Med. Chem. Lett. 2008, 18, 913. (c) Tera, M.; Iida, K.; Ishizuka, H.; Takagi, M.; Suganuma, M.; Doi, T.; Shin-ya, K.; Nagasawa, K. Chembiochem. 2009, 10, 431.

9. $\quad \mathrm{DCC}=N, N^{\prime}$-dicyclohexylcarbodiimide. Sheehan, J. C.; Hess, G. P. J. Am Chem Soc. 1955, 77, 1067.

10. $\mathrm{HOBt}=N$-hydroxybenzotriazole. W. König. W.; Geiger, R. Chem. Ber. 1970, 103, 2034.

11. DAST = diethylaminosulfur trifluoride (a) Burrell, G.; Evans, J. M.; Jones, G. E.; Stemp, G. Tetrahedron Lett. 1990, 31, 3649. (b) Lafargue, P.; Guenot, P.; Lellouche, J.-P. Heterocycles 1995, 41, 947. (c) Phillips, A. J.; Uto, Y.; Wipf, P.; Reno, M. J.; Williams, D. R. Org. Lett. 2000, 2, 1165.

12. $\mathrm{DBU}=$ 1,8-diazabicyclo[5.4.0]undec-7-ene. Williams, D. R.; Lowder, P. D.; Gu, Y.-G.; Brooks, D. A. Tetrahedron Lett. 1997, 38, 331. 
13. PyBroP = bromo-trispyrrolidino-phosphonium hexafluorophosphate. (a) Coste, J.; Dufour, M.-N.; Pantaloni, A.; Castro, B. Tetrahedron Lett. 1990, 31, 669. (b) Coste, J.; Frérot, E.; Jouin, P.; Castro, B. Tetrahedron Lett. 1990, 32, 1967.

14. DIEA $=N, N$-diisopropylethylamine.

15. HATU $=O$-(7-azabenzotriazol-1-yl)- $N, N, N^{\prime}, N^{\prime}$-tetramethyluronium hexafluorophosphate. Deeley, J.; Pattenden, G. Chem. Commun. 2005, 6, 797.

16. DPPA = diphenyl phosphorazidate. Shioiri, T.; Ninomiya, K.; Yamada, S. J. Am. Chem. Soc. 1972, 94, 6203.

17. DMAP $=4$-dimethylaminopyridine.

18. Butler, S. J.; Jolliffe, K. A. Org. Biomol. Chem. 2011,9, 3471. 